\title{
Enhanced Iron and Zinc Accumulation in Genetically Engineered Wheat Plants Using Sickle Alfalfa (Medicago falcata L.) Ferritin Gene
}

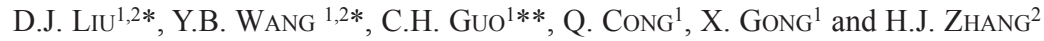 \\ ${ }^{1}$ Key Laboratory of Molecular and Cytogenetic of Heilongjiang Province/College of Life Science and \\ Technology, Harbin Normal University, Harbin 150025, China \\ ${ }^{2}$ Crop Breeding Institute, Heilongjiang Academy of Agricultural Sciences, Harbin 150086, China
}

\author{
(Received 22 October 2014; Accepted 3 June 2015; \\ Communicated by A. Börner)
}

\begin{abstract}
Iron deficiency is the most common nutritional disorder, affecting over $30 \%$ of the world's human population. The primary method used to alleviate this problem is nutrient biofortification of crops so as to improve the iron content and its availability in food sources. The over-expression of ferritin is an effective method to increase iron concentration in transgenic crops. For the research reported herein, sickle alfalfa (Medicago falcata L.) ferritin was transformed into wheat driven by the seed-storage protein glutelin GluB-1 gene promoter. The integration of ferritin into the wheat was assessed by PCR, RT-PCR and Western blotting. The concentration of certain minerals in the transgenic wheat grain was determined by inductively coupled plasma-atomic emission spectrometry, the results showed that grain Fe and $\mathrm{Zn}$ concentration of transgenic wheat increased by $73 \%$ and $44 \%$ compared to nontransformed wheat, respectively. However, grain $\mathrm{Cu}$ and $\mathrm{Cd}$ concentration of transgenic wheat grain decreased significantly in comparison with non-transformed wheat. The results suggest that the over-expression of sickle alfalfa ferritin, controlled by the seed-storage protein glutelin GluB-1 gene promoter, increases the grain $\mathrm{Fe}$ and $\mathrm{Zn}$ concentration, but also affects the homeostasis of other minerals in transgenic wheat grain.
\end{abstract}

Keywords: sickle alfalfa, ferritin, wheat, transformation, Fe, Zn

Abbreviations: BLAST, Basic Local Alignment Search Tool; NCBI, National Center for Biotechnology Information; PCR, polymerase chain reaction; RT-PCR, reverse transcription PCR; WHO, world health organization; IAA: Indole-3-acetic acid; MET: paclobutrazol, 2,4D: 2-(2,4-dichlorophenoxy)acetic acid.

\section{Introduction}

Iron $(\mathrm{Fe})$ is an essential micronutrient for most organisms, and its deficiency is the most common and widespread nutritional disorder in the world (WHO 2014). More than 30\% of the world's population, $\sim 2$ billion people, suffers from iron-deficiency-related anae-

\footnotetext{
*The first two authors contributed equally.

**Corresponding author; E-mail: kaku2008@hotmail.com
} 
mia; the major health effects of iron deficiency include impaired physical, reduced cognitive development and reduced work productivity that decreases the work capacity of individuals and entire populations, bringing serious economic consequences and obstacles to national development (WHO 2014).

Three approaches, food biofortification, food fortification and micronutrient supplementation, have been applied to the problem of micronutrient deficiencies (Masuda et al. 2013). Improving crop varieties using modern genetic engineering or conventional breeding to increase the iron content has the advantage of sustainability, i.e., the biofortified crops will not require further investment, unlike the addition of iron-containing chemicals to food or the use of iron supplements in pill form (Gomez et al. 2010). Hence, it is best to develop iron-biofortified foods through the application of technology.

Ferritin is an intracellular plastid protein that controls iron sequestration, storage, and release (Koorts and Viljoen 2007). Thus, ferritin is an important gene for the regulation of iron accumulation in plants. Modern genetic engineering is being used to modify major staple food crops to increase iron accumulation. Over-expression of ferritin in crops has been an effective strategy for increasing iron levels (Goto et al. 1998; Lucca et al. 2002; Vasconcelos et al. 2003; Drakakaki et al. 2005; Qu et al. 2005; Borg et al. 2012; Masuda et al. 2012; Sui et al. 2012; Kanobe et al. 2013). Drakakaki et al. (2000) transformed soybean ferritin into wheat and rice, under the control of the constitutive maize ubiquitin-1 gene promoter, the iron level increased significantly in the vegetative tissues of transformant plants. Soybean ferritin expressed in the transgenic T1 rice and under the control of the seed storage protein glutelin GluB-1 gene promoter increased the iron concentration of self-pollinated T1 seeds threefold compared with that of non-transformed plants (Goto et al. 1999). Additionally, Borg et al. (2012) transformed endogenous wheat ferritin, driven by the HMW-GS 1DX5 gene promoter, into the wheat cultivar Bob White, the iron concentration of the resulting transgenic line increased by $50 \%$ to $85 \%$. The aforementioned studies demonstrated the potential for breeding transgenic ferritin-containing crops to produce substantial amounts of iron.

In addition to rice, wheat (Triticum aestivum) is an important food crop, cultivated by $40 \%$ of the population throughout the world and provides humans with $20 \%$ of total calories and protein requirement (Gupta et al. 2008). Thus, fortification of wheat is a highly desirable approach to overcome iron deficiency in humans. After cloning, sickle alfalfa (Medicago falcata L.) ferritin, driven by the promoter of the seed-storage protein glutelin GluB1 gene, was transformed into wheat, grain Fe and Zn concentration of transgenic wheat increased by $73 \%$ and $44 \%$ compared with non-transformed wheat, respectively. This work may contribute to alleviating iron-deficiency anemia and serve to improve public health.

\section{Materials and Methods}

\section{Isolation of ferritin from sickle alfalfa}

Sickle alfalfa was grown in the experimental field of Harbin Normal University, China. When the seedlings developed with three true leaves, leaf samples were collected for RNA extraction. Total RNA was extracted from samples of sickle alfalfa leaves as de- 
scribed by Cui et al. (2006). Sickle alfalfa ferritin was isolated from total RNA as described in Guo et al. (2008). The orthologous sequence search was performed with the basic local alignment search tool (BLAST) provided by the National Centre for Biotechnology Information databases (http://www.ncbi.nlm.nih.gov/BLAST/). The alignment of orthologous ferritin was performed by DNAMAN software (Lynnon, Quebec, Canada).

\section{Construction of seed-specific expression vector $p B l u-G l u B-1 / F e r$}

Ferritin cDNA was designed to generate a 756 bp fragment containing an open reading frame, which was inserted into a modified pBlueskript SK+ vector, driven by the seed specific expression promoter of the GluB-1 gene, and terminated by the Nos terminator. Sickle alfalfa ferritin was inserted between the $\mathrm{SacI}$ and BamHI sites to generate the expression vector pBlu-GluB-1/Fer (Fig. 1).

\section{Wheat genetic transformation by particle bombardment}

Wheat cultivar Longfu16 was used in this study. Immature embryos (13-14 days Postathesis) were explanted and cultured in callus induction medium (MS +2,4-D $2 \mathrm{mg} / \mathrm{L}+$ sucrose $50 \mathrm{~g} / \mathrm{L}+$ agar $5 \mathrm{~g} / \mathrm{L}$ ) as described by Quan et al. (2007). Explants were cultured for 7 days in dark at $25^{\circ} \mathrm{C}$. The target tissue was then transferred to medium containing $0.2 \mathrm{M}$ mannitol for 4-6 h prior to bombardment and 16-18 $\mathrm{h}$ after bombardment. Particle bombardment was carried out using gold particles coated with a mixture of expression vector pBlu-GluB-1/Fer. After bombardment, cultures were transferred to callus induction medium and incubated for 14 days in the dark. Embryogenesis callus was transferred to $1 / 2 \mathrm{MS}$ medium supplemented with $5 \mathrm{mg} / \mathrm{L}$ zeatin, and $2 \mathrm{mg} / \mathrm{L}$ bialaphos maintained under light. Plants were regenerated in the presence of bialaphos at $25^{\circ} \mathrm{C}$. Resistant regenerated shoots acclimated in $1 / 2 \mathrm{MS}$ medium supplemented with $0.3 \mathrm{mg} / \mathrm{L} \mathrm{IAA}$ and 0.5 $\mathrm{mg} / \mathrm{L}$ MET for 14 days and were transplanted to pots in the greenhouse $\left(28^{\circ} \mathrm{C}, 25,000\right.$ lux, Light/Dark, 16/8 h) (Quan et al. 2007). Wheat grain was harvested from each plant separately at maturity.

\section{Molecular analysis of transgenic wheat lines by PCR and RT-PCR}

Genomic DNA, extracted from T1 transgenic plants, non-transformed wheat plant as negative control, plasmid DNA as positive control, was used for PCR analysis. The PCR solution mixture contained $1 \times$ Taq polymerase buffer, $0.2 \mathrm{mM}$ of each $\mathrm{dNTP}, 10 \mathrm{pM}$ each

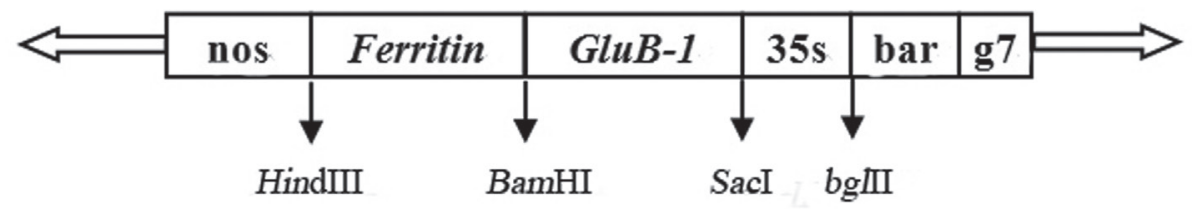

Figure 1. Schematic outline of the plant expressing vector pBlu-GluB-1/Fer 
of the primers, fer-1: TCGTGGGTCATTTCTCAAA and fer-2: AAAGACAGAGCCAATTCCATG (Fig. 2), and 1 unit Taq polymerase. The PCR condition was: $94{ }^{\circ} \mathrm{C}$, $5 \mathrm{~min}$ for the initial melting; 35 cycles at $94^{\circ} \mathrm{C}$ for $40 \mathrm{sec}, 58^{\circ} \mathrm{C}$ for $40 \mathrm{sec}$, and $72{ }^{\circ} \mathrm{C}$ for $40 \mathrm{sec}$; and a final extension step at $72^{\circ} \mathrm{C}$ for $5 \mathrm{~min}$. PCR-positive wheat plants were used for RT-PCR to determine the transgene expression. Total RNA was isolated from T1 transgenic wheat plant and the non-transformed wheat plant, and then $1 \mathrm{mg}$ total RNA was used for each first-strand cDNA synthesis as described above. Next, $5 \mathrm{ml}$ of each first-strand cDNA solution was provided for template alone with fer- 1 and fer- 2 for PCR amplification. Plasmid DNA was provided for template for positive control. The PCR conditions were described above. PCR and RT-PCR products were analyzed by $1 \%$ agarose gel electrophoresis.

Western blotting was performed to examine the expression levels of the sickle alfalfa ferritin in wheat grain. Three T1 transgenic wheat plants and one non-transformed wheat plant were examined. Total protein was extracted from the seeds, which had been ground into powders, in $200 \mathrm{mM}$ Tris- $\mathrm{HCl}$ pH8.0, $100 \mathrm{mM} \mathrm{NaCl}, 400 \mathrm{mM}$ sucrose, $10 \mathrm{mM}$ EDTA, $14 \mathrm{mM}$ 2-mercaptaethanol and $0.05 \%$ (w/v) Tween-20. Protein separation by SDS-polyacrylamide gel electrophoresis and transferred onto nitrocellulose membrane as described in Goto et al. (1999).

\section{Thousand grain weight (TGW) and mineral concentration measurement}

Transgenic wheat, identified by PCR, RT-PCR and western blotting techniques, and nontransformed wheat was sown in pots $(26 \mathrm{~cm}$ in diameter and $24 \mathrm{~cm}$ high) at Harbin Normal University, Harbin, China $\left(45^{\circ} \mathrm{N}, 126^{\circ} \mathrm{E}\right)$. Pots contained a mix of black soil and marsh soil (4:1). The following nutrients $\left(\mathrm{CO}\left(\mathrm{NH}_{2}\right)_{2} 2 \mathrm{~g} /\right.$ pot, $\left(\mathrm{NH}_{4}\right)_{2} \mathrm{HPO}_{4} 3 \mathrm{~g} /$ pot, $\mathrm{K}_{2} \mathrm{SO}_{4}$ $1 \mathrm{~g} / \mathrm{pot}$ ) were added to soil mix before sowing. Plant density was standardized to 7 plants per pot; and all transgenic lines and non-transformed wheat were replicated 3 times. The location of transgenic wheat and non-transformed wheat was randomized to reduce location effects. Plants were grown under natural condition, and frequent irrigations were applied during the whole life cycle in order to prevent drought stress. Grain of T3 transgenic wheat and non-transformed wheat were used for TGW in 2010-2011. TGW of each transgenic line and non-transformed wheat was estimated on a sample of 250 grains three times, and each value was average of three replications. Mineral concentration was detected by inductively coupled plasma atomic emission spectrometry (ICP-OES, OPTIMA 3300 DV, Perkin Elmer, USA) at the Determination Center for Agro-products Quality of Heilongjiang Province, China. The concentrations of minerals were detected at wave lengths of $238.204 \mathrm{~nm}(\mathrm{Fe}), 213.856 \mathrm{~nm}(\mathrm{Zn}), 317.33 \mathrm{~nm}(\mathrm{Ca}), 324.754 \mathrm{~nm}(\mathrm{Cu}), 293.930$ $\mathrm{nm}(\mathrm{Mn})$ and $214.438 \mathrm{~nm}(\mathrm{Cd})$ in the whole grain. The data of TGW and grain mineral concentration was used for analysis of variance (ANOVA) to evaluate the significance of the differences between transgenic wheat and non-transformed wheat. 


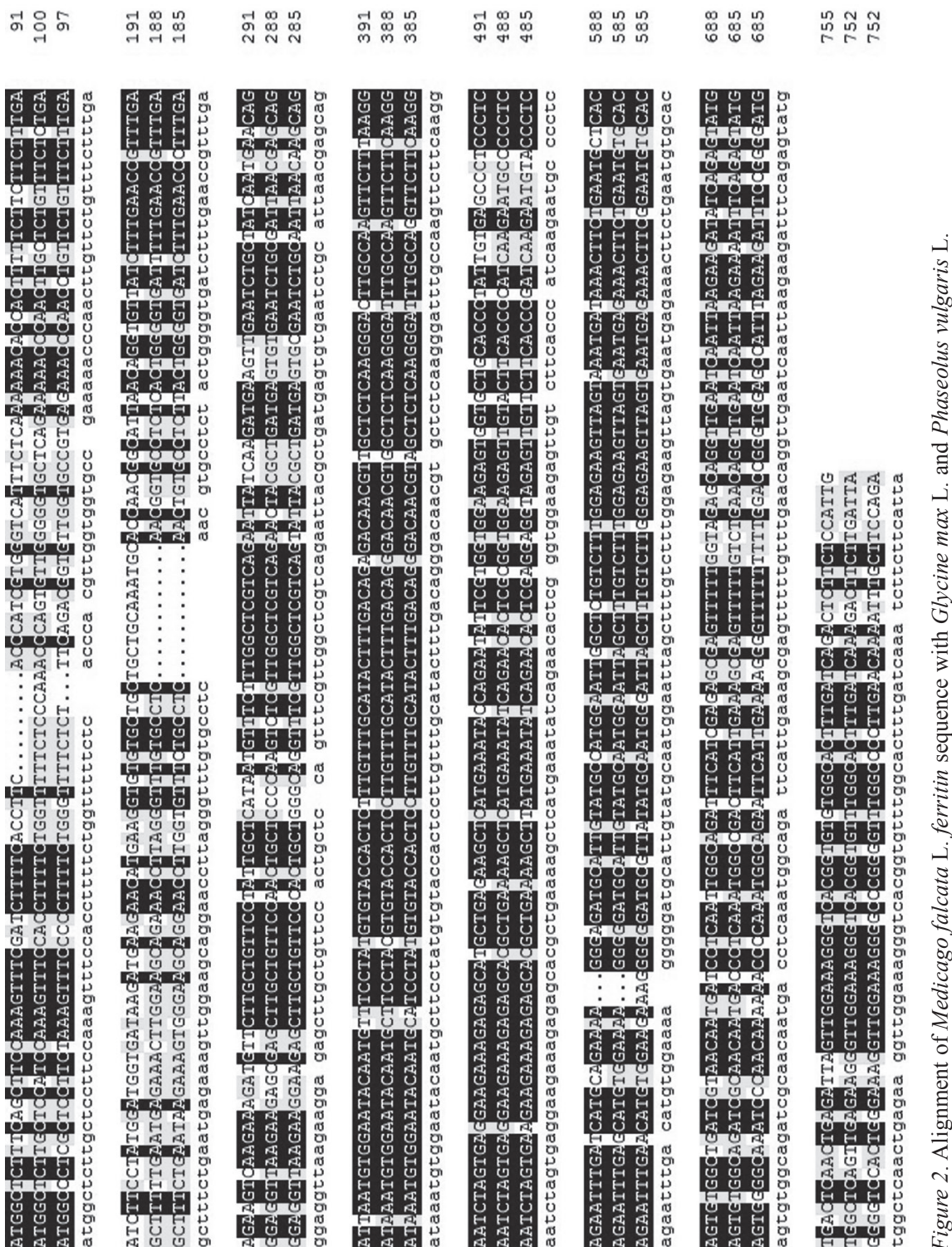

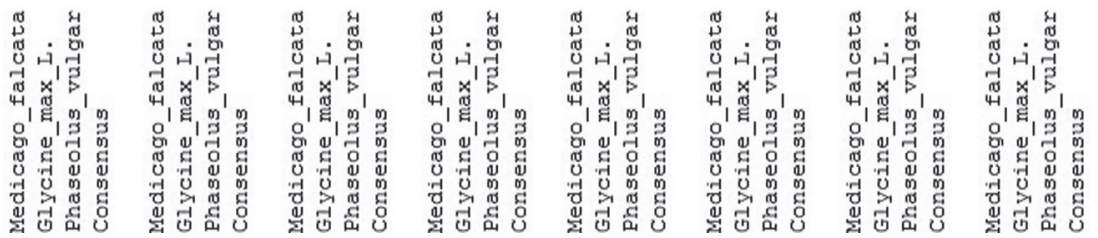




\section{Results}

Sequence analysis

Sickle alfalfa ferritin (GenBank EF535605.1) was successfully cloned and sequenced, the analysis of the entire cDNA showed that it is $756 \mathrm{bp}$ in length, so that it encodes ferritin containing 252 residues (Guo et al. 2008). The BLAST results indicate that the sickle alfalfa ferritin sequence has $73 \%$ nucleotide identity with that of Phaseolus vulgaris (genbank KFO33276.1) (Lucca et al. 2002) and 78\% nucleotide identity with Glycine $\max$ (GenBank M64337.1) (Goto et al. 1999) (Fig. 2).

\section{Molecular analysis of transgenic wheat}

Using PCR, a specific amplicon of $500 \mathrm{bp}$, corresponding to the expected size of sickle alfalfa ferritin, was found in the transgenic wheat and the positive control, whereas it was absent in non-transformed wheat (Fig. 3). RT-PCR also produced a specific 500-bp amplicon using total RNA from the transgenic wheat and the positive control, but not from the non-transformed wheat (Fig. 4). These data suggest that sickle alfalfa ferritin was integrated into the transgenic wheat.

Western blotting was obtained to detect the expression of sickle alfalfa ferritin in the transgenic wheat seeds, with a $28-\mathrm{kDa}$ band (Fig. 5, lanes 1, 2, and 3) detected when

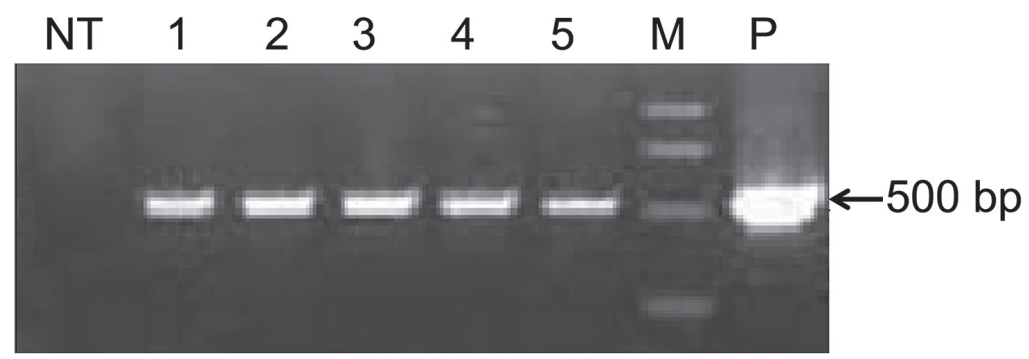

Figure 3. Molecular analysis of transgenic wheat using PCR

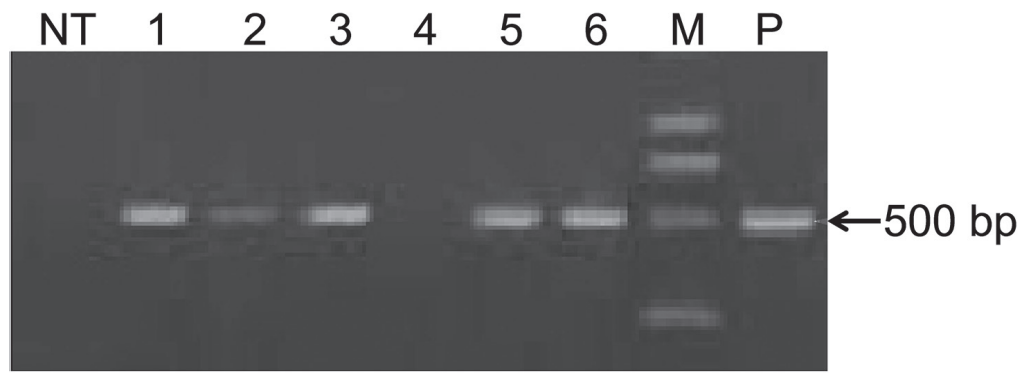

Figure 4. Molecular analysis of transgenic wheat using RT-PCR 


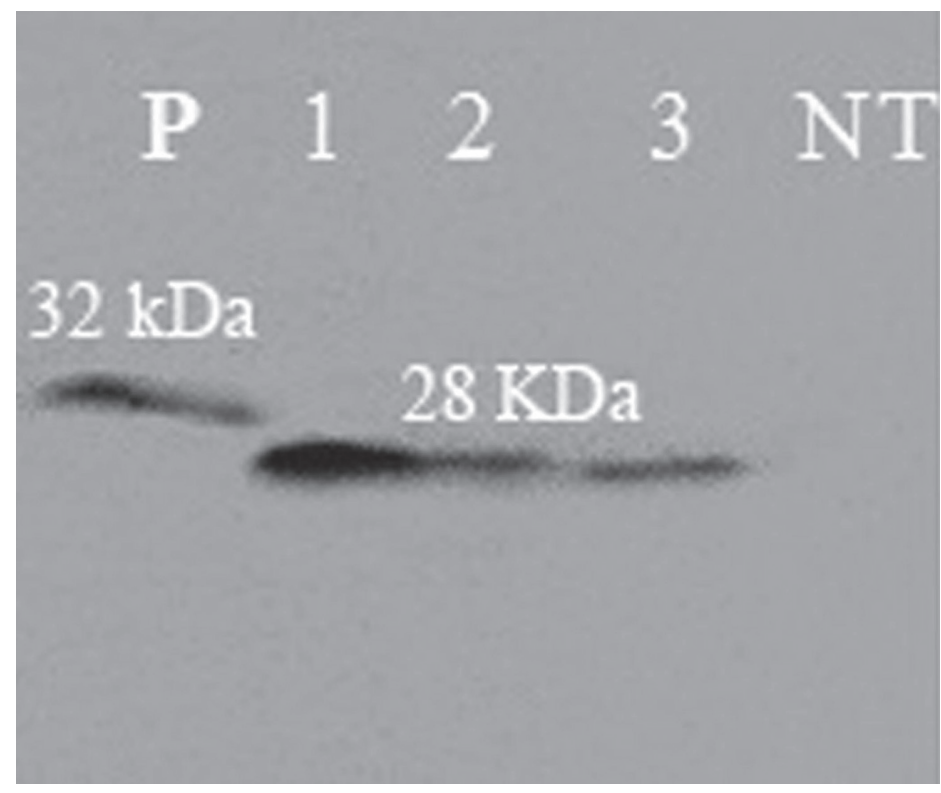

Figure 5. Western blotting of ferritin

NT, Non-transformants; P, Positive control; M:DL2000

transgenic wheat grain protein was probed, but not when non-transformed wheat grain protein was probed. For the positive control, a 32-kDa band was detected, which, we speculate, may be the precursor of ferritin. These results confirmed that sickle alfalfa ferritin was expressed in the transgenic wheat grain.

\section{Enhanced accumulation of Fe and Zn concentration in the transgenic wheat grain}

TGW of transgenic wheat and non-transformed wheat was $36.68 \mathrm{~g}$ and $36.41 \mathrm{~g}$ in average, respectively. There is no significant difference between TGW of transgenic wheat and non-transformed wheat, although TGW of transgenic wheat is higher than that of non-transformed wheat. Inductively coupled plasma-atomic emission spectrometry was used to measure the grain $\mathrm{Fe}, \mathrm{Zn}, \mathrm{Ca}, \mathrm{Cu}, \mathrm{Mn}$ and $\mathrm{Cd}$ concentration in four transgenic wheat lines and non-transformed wheat. The result showed that grain Fe and $\mathrm{Zn}$ concentration of transgenic wheat increased by $73 \%$ and $44 \%$ compared to non-transformed wheat, respectively. However, grain $\mathrm{Cu}$ and $\mathrm{Cd}$ concentration of transgenic wheat significantly decreased by $22 \%$ and $65 \%$ compared to non-transformed wheat, respectively. Grain Ca concentration of the transgenic wheat tended to decline in comparison to that of non-transformed wheat. Grain Mn concentration of the transgenic wheat fluctuated in comparison with that of non-transformed wheat. As can be seen from Table 1 that TGW of transgenic lines P1, P2 was significant higher than that of non-transformed wheat $(p<0.05)$ and TGW of transgenic lines P3, P4 showed no significant difference with that 
Table 1. Elemental analysis on seeds of transgenic wheat and thousand grain weight

\begin{tabular}{|c|c|c|c|c|c|c|c|}
\hline $\begin{array}{c}\text { 岂 } \\
\text { 崩 }\end{array}$ & $\begin{array}{c}\mathrm{Fe} \\
(\mathrm{mg} / \mathrm{kg})\end{array}$ & $\begin{array}{c}\mathrm{Zn} \\
(\mathrm{mg} / \mathrm{kg})\end{array}$ & $\begin{array}{c}\mathrm{Ca} \\
(\mathrm{mg} / \mathrm{kg})\end{array}$ & $\begin{array}{c}\mathrm{Mn} \\
(\mathrm{mg} / \mathrm{kg})\end{array}$ & $\begin{array}{c}\mathrm{Cu} \\
(\mathrm{mg} / \mathrm{kg})\end{array}$ & $\begin{array}{c}\mathrm{Cd} \\
(\mu \mathrm{g} / \mathrm{kg})\end{array}$ & $\begin{array}{c}\mathrm{TGW} \\
(\mathrm{g})\end{array}$ \\
\hline $\mathrm{NT}$ & $44.94^{\mathrm{B}} \pm 1.43$ & $37.49^{\mathrm{B}} \pm 2.89$ & $378.23^{\mathrm{a}} \pm 6.31$ & $28.55^{\mathrm{c}} \pm 0.89$ & $5.70^{\mathrm{a}} \pm 0.14$ & $74.56^{\mathrm{A}} \pm 1.93$ & $36.41^{\mathrm{cd}} \pm 0.06$ \\
$\mathrm{P} 1$ & $77.50^{\mathrm{A}} \pm 1.03$ & $53.78^{\mathrm{A}} \pm 2.36$ & $374.23^{\mathrm{a}} \pm 7.20$ & $27.59^{\mathrm{c}} \pm 0.30$ & $5.23^{\mathrm{b}} \pm 0.07$ & $27.43^{\mathrm{B}} \pm 0.93$ & $36.83^{\mathrm{b}} \pm 0.062$ \\
$\mathrm{P} 2$ & $77.61^{\mathrm{A}} \pm 1.15$ & $53.84^{\mathrm{A}} \pm 1.96$ & $309.83^{\mathrm{b}} \pm 4.92$ & $24.89^{\mathrm{d}} \pm 0.16$ & $4.18^{\mathrm{c}} \pm 0.09$ & $26.06^{\mathrm{B}} \pm 0.39$ & $37.13^{\mathrm{a}} \pm 0.03$ \\
$\mathrm{P} 3$ & $78.01^{\mathrm{A}} \pm 1.11$ & $53.92^{\mathrm{A}} \pm 1.10$ & $359.96^{\mathrm{ab}} \pm 10.24$ & $33.50^{\mathrm{b}} \pm 0.88$ & $4.21^{\mathrm{c}} \pm 0.11$ & $27.05^{\mathrm{B}} \pm 0.62$ & $36.52^{\mathrm{c}} \pm 0.05$ \\
$\mathrm{P} 4$ & $78.06^{\mathrm{A}} \pm 0.82$ & $54.07^{\mathrm{A}} \pm 3.01$ & $377.43^{\mathrm{a}} \pm 9.02$ & $36.13^{\mathrm{a}} \pm 0.89$ & $4.37^{\mathrm{c}} \pm 0.07$ & $23.06^{\mathrm{B}} \pm 0.55$ & $36.22^{\mathrm{d}} \pm 0.05$ \\
\hline
\end{tabular}

Data in columns displaying the same letters are not significantly different at $p<0.05$ by one-way ANOVA. Significantly different $p<0.01$ (Capital letters) and $p<0.05(0.05)$.

of non-transformed wheat, but grain Fe and $\mathrm{Zn}$ concentration of transgenic lines (P1, P2, P3 and P4) increased significantly compared to that of non-transformed wheat $(p<0.01)$. And there is no significant difference in grain $\mathrm{Fe}$ and $\mathrm{Zn}$ concentration between transgenic lines P1, P2 and P3, P4, although a significant difference was found between TGW of transgenic lines P1, P2 and P3, P4. So, grain Fe and Zn concentration in transgenic wheat was not correlated with TGW.

\section{Discussion}

Modern genetic and molecular technologies provide strategies to develop foods with higher iron content. Over-expression of ferritin to increase the amount of iron in plants has been applied to crop breeding (Goto et al. 1999; Drakakaki et al. 2000; Lucca et al. 2001; Vasconcelos et al. 2003; Qu et al. 2005). Eagling et al. (2014) discovered that cultivars with greater Fe and $\mathrm{Zn}$ concentrations in whole meal flour were also found to contain greater concentrations in white flour. Thus, breeding crop cultivars that produce larger amounts of iron is a feasible method to provide more iron in food.

In the present study, over-expression of ferritin increased grain $\mathrm{Fe}$ and $\mathrm{Zn}$ concentration of transgenic wheat by $73 \%$ and $44 \%$, respectively compared to non-transformed wheat, while other mineral concentration was also affected by expression of ferritin, which had been reported by several studies (Qu et al. 2005; Drakakaki et al. 2005; Vasconcelos et al. 2003), Kanobe consider that over-expression of ferritin affects the native mineral homeostasis in the transgenic plant (Kanobe et al. 2013).

The promoter selected to control ferritin expression is critical to iron accumulation in specific tissues. Transgenic tobacco and lettuce plants with a larger amount of iron than that found in the corresponding non-transformed crop have been produced by transformation with soybean ferritin cDNA driven by the cauliflower mosaic virus $35 \mathrm{~S}$ gene promoter (Goto et al. 1998, 2000). The iron concentration in the leaves of these transformants is $20 \%$ to $70 \%$ greater than that of non-transformants. The expression of soybean ferritin under the control of the endosperm-specific glutelin gene promoter improved the Fe and $\mathrm{Zn}$ concentrations in transgenic indica rice grain (Vasconcelos et al. 2003). The over-expression of endogenous rice ferritin under the control of the OsglutelinA2 gene promoter revealed a 2.1-fold enhancement in Fe concentration and a 1.36-fold Zn con- 
centration enhancement, in the transgenic aromatic milled rice grain (Paul et al. 2012). In this work, expression of ferritin, controlled by the promoter of the seed-storage protein glutelin GluB-1 gene, led to significantly increased Fe and $\mathrm{Zn}$ accumulation in transgenic wheat grain.

Grain Fe and $\mathrm{Zn}$ concentration of wheat is varied in different genotypes (Shi et al. 2009; Zhang et al. 2007; Oury et al. 2006) and environmental factors, including fertilizer application (Liu et al. 2014; Syltie et al. 2005; Kutman et al. 2010), drought (Amiri et al. 2015) and $\mathrm{CO}_{2}$ enrichment (Fernando et al. 2014). In the present study, transgenic wheat and non-transformed wheat were in the general genetic background and grew in the same environment. So, increased grain Fe and $\mathrm{Zn}$ concentration is not due to genotype and environment factors. In addition, Ozturk (2006) and Regvar (2011) stated that most Fe and $\mathrm{Zn}$ are mainly distributed in the aleurone layer. So, grain Fe and $\mathrm{Zn}$ concentration had negative correlation to grain size and TGW value due to the proportion of aleurone in whole grain. However, several studies reported that grain Fe, Zn concentration was not correlated with TGW (Shi et al. 2013; Amiri et al. 2015; Zhao et al. 2009). So, in this study, grain Fe and $\mathrm{Zn}$ concentration of transgenic wheat increased significantly because of expression of ferritin, instead of TGW, genotype and environment.

In order to alleviate iron deficiency in staple food crops, it is an affective way to improve grain Fe and $\mathrm{Zn}$ concentration by breeding new cultivars with higher iron concentration, while it is necessary to improve iron availability by reducint phytate concentration. Such a multi-pronged approach, combining these features, would further improve the iron absorption of wheat grain as a food source.

\section{References}

Amiri, R., Bahraminejad, S., Sasani, S., Jalali-Honarmand, S., Fakhri, R. 2015. Bread wheat genetic variation for grain's protein, iron and zinc concentrations as uptake by their genetic ability. Eur. J. Agron. 67:20-26.

Borg, S., Brinch-Pedersen. H., Tauris, B., Madsen, L.H., Darbani, B., Noeparvar, S., Holm, P.B. 2012. Wheat ferritins: Improving the iron content of the wheat grain. J. Cereal Sci. 56:204-213.

Cui, S.P., Kang, Z.S., Jie, Z.H., Yu, X.M. 2006. A method of quickly extracting total RNA from wheat leaves. Acta Bot. Boreali-Occident. Sin. 26:314-318. (in Chinese)

Drakakaki, G., Christou, P., Stöger, E. 2000. Constitutive expression of soybean ferritin cDNA in transgenic wheat and rice results in increased iron levels in vegetative tissues but not in seeds. Transgenic Res. 9:445-452.

Drakakaki, G., Marcel, S., Glahn, R.P., Lund, E.K., Pariagh, S., Fischer, R., Christou, P., Stoger, E. 2005. Endosperm-specific co-expression of recombinant soybean ferritin and aspergillus phytase in maize results in significant increases in the levels of bioavailable iron. Plant Mol. Biol. 59:869-880.

Eagling, T., Neal, A.L., McGrath, S.P., Fairweather-Tait, S., Shewry, P.R., Zhao, F.J. 2014. Distribution and speciation of iron and zinc in grain of two wheat genotypes. J. Agric. Food Chem. 62:708-716.

Fernando, N., Panozzo, J., Tausz, M., Norton, R.M., Neumann, N., Fitzgerald, G.J. 2014. Elevated $\mathrm{CO}_{2}$ alters grain quality of two bread wheat cultivars grown under different environmental conditions. Agr. Ecosyst. Environ. 185:24-33.

Gomez-Galera, S., Rojas, E., Sudhakar, D., Zhu, C., Pelacho, A.M., Capell, T., Christou, P. 2010. Critical evaluation of strategies for mineral fortification of staple food crops. Transgenic Res. 19:165-180.

Goto, F., Yoshihara, T., Saiki, H. 1998. Iron accumulation in tobacco plants expressing soybean ferritin gene. Transgenic Res. 7:173-180. 
Goto, F., Yoshihara, T., Saiki, H. 2000. Iron accumulation and enhanced growth in transgenic lettuce plants expressing the iron-binding protein ferritin. Theor. Appl. Genet. 100:658-664.

Goto, F., Yoshihara, T., Shigemoto, N., Toki, S., Takaiwa, F. 1999. Iron fortification of rice seed by the soybean ferritin gene. Nat. Biotechnol. 17:282-286.

Guo, C.H, Wang, Y.B., Li, L.Y., Sha, Y.Q. 2008. Cloning and sequence analyzing of ferritin cDNA from Medicago falcate L. J. of Harbin Institute of Technol. 41:141-145. (in Chinese)

Gupta, P.K., Mir, R.R., Mohan, A., Kumar, J. 2008. Wheat genomics: present status and future prospects. Int. J. Plant Genomics. Free PMC article. doi: 10.1155/2008/896451. pp. 1-36. http://www.ncbi.nlm.nih.gov/ pmc/articles/PMC2397558/

Kanobe, M.N., Rodermel, S.R., Bailey, T., Scott, M.P. 2013. Changes in endogenous gene transcript and protein levels in maize plants expressing the soybean ferritin transgene. Front Plant Sci. 4:196.

Koorts, A.M., Viljoen, M. 2007. Ferritin and ferritin isoforms I: Structure-function relationships, synthesis, degradation and secretion. Arch. Physiol. Biochem. 113:30-54.

Kutman, U.B., Yildiz, B., Ozturk, L., Cakmak, I. 2010. Biofortification of durum wheat with zinc through soil and foliar applications of nitrogen. Cereal Chem. 87:1-9.

Liu, H., Wang, Z.H., Li, F., Li, K., Yang, N., Yang, Y. 2014. Grain iron and zinc concentrations of wheat and their relationships to yield in major wheat production areas in China. Field Crop Res. 156:151-160.

Lucca, P., Hurrell, R., Potrykus, I. 2001. Genetic engineering approaches to improve the bioavailability and the level of iron in rice grains. Theor. Appl. Genet. 102:392-397.

Lucca, P., Hurrell, R., Potrykus, I. 2002. Fighting iron deficiency anemia with iron-rich rice. J. Am. Coll. Cardiol. 21:184S-190S.

Masuda, H., Ishimaru, Y., Aung, M.S., Kobayashi, T., Kakei, Y., Takahashi, M., Higuchi, K., Nakanishi, H., Nishizawa, N.K. 2012. Iron biofortification in rice by the introduction of multiple genes involved in iron nutrition. Sci. Rep. 2:543.

Masuda, H., Kobayashi, T., Ishimaru, Y., Takahashi, M., Aung, M.S., Nakanishi, H., Mori, S., Nishizawa, N.K. 2013. Iron-biofortification in rice by the introduction of three barley genes participated in mugineic acid biosynthesis with soybean ferritin gene. Front Plant Sci. 4:132.

Oury, F.X., Leenhardt, F., Rémésy, C., Chanliaud, E., Duperrier, B., Balfourier, F., Charmet, G., 2006. Genetic variability and stability of grain magnesium, zinc and iron concentrations in bread wheat. Eur. J. Agron. 25:177-185.

Ozturk, L., Yazici, M.A., Yucel, C., Torun, A., Cekic, C., Bagci, A., Ozkan, H., Braun, H.-J., Sayers, Z., Cakmak, I. 2006. Concentration and localization of zinc during seed development and germination in wheat. Physiologia Plantarum 128:144-152.

Paul, S., Ali, N., Gayen, D., Datta, S.K., Datta, K. 2012. Molecular breeding of Osfer 2 gene to increase iron nutrition in rice grain. GM Crops and Food 3:310-316.

Qu, L., Yoshihara, T., Ooyama, A. Goto, F. Takaiwa, F. 2005. Iron accumulation does not parallel the high expression level of ferritin in transgenic rice seeds. Planta 222:225-233.

Quan, J.L., He, Y.K., Chen, Y.f., Li, C.L., Guo, D.W., Han, D.J., Ling, Y. 2007. Establishment of efficient acceptor system for gene transformation by microprojectile bombardment in wheat. J. Northwest A\&F Univ. (Natural Science Edition). 35:117-122. (in Chinese)

Regvar, M., Eichert, D., Kaulich, B., Gianoncelli, A., Pongrac, P., Vogel-Mikus, K., Kreft, I. 2011. New insights into globoids of protein storage vacuoles in wheat aleurone using synchrotron soft X-ray microscopy. J. Exp. Bot. 62:3929-3939.

Shi, R.1., Zou, C.Q., Rui, Y.K., Zhang, X.Y., Xia, X.P., Zhang, F.S. 2009. Application of ICP-AES to detecting nutrients in grain of wheat core collection of China. Spectroscopy and Spectral Analysis 29:1104-1107.

Shi, R.L., Tong, Y.P., Jing, R.L., Zhang, F.S., Zou, C.Q. 2013. Characterization of quantitative trait loci for grain minerals in hexaploid wheat (Triticum aestivum L.). J. Integr. Agr. 12:1512-1521.

Sui, X., Zhao, Y., Wang, S., Duan, X., Xu, L., Liang, R. 2012. Improvement Fe content of wheat (Triticum aestivum) grain by soybean ferritin expression cassette without vector backbone sequence. J. Agric. Biotechnol. 20:766-773. (in Chinese)

Syltie, P.W., Dahnke, W.C. 2005.Mineral and protein content, test weight and yield variations of hard spring wheat grain as influenced by fertilization and cultivar. Plant Food Human Nutri. 32:32-39. 
Vasconcelos, M., Datta, K., Oliva, N., Khalekuzzaman, M., Torrizo, L., Krishnan, S., Oliveira, M., Goto, F., Datta, S.K. 2003. Enhanced iron and zinc accumulation in transgenic rice with the ferritin gene. Plant Sci. 164:371-378.

WHO 2014. Micronutrient deficiencies. http://www.who.int/nutrition/topics/ida/en/

Zhang,Y., Wang, D.S., Zhang, Y., He, Z.H. 2007.Variation of major mineral elements concentration and their relationships in grain of Chinese wheat. Scientia Agricultura Sinica. 40:1871-1876.

Zhao, F.J., Su, Y.H., Dunham, S.J., Rakszegi, M., Bedo, Z., McGrath, S.P., Shewry, P.R., 2009. Variation in mineral micronutrient concentrations in grain of wheat lines of diverse origin. J. Cereal Sci. 49:290-295. 